\title{
RADIOLOGICAL MAPPING OF NEPALESE CALVARIA.
}

\author{
Manoj Bhattarai
}

\begin{abstract}
Introduction

Skull has cranial vault and base. The cranial vault is called as calvarium which roofs the cranial cavity (brain box).Cranial vault consists of frontal, parietal and occipital bones. Total thickness of calvarial bones includes outer table, diploe and inner table. Diploe is made up of spongy bone whereas outer and inner table made up of compact bone.
\end{abstract}

\section{Objective}

To measure the thickness of Nepalese calvarial bones i.e. Frontal, Parietal and Occipital.

\section{Methods}

It is a hospital base cross-sectional study. CT records of one hundred and fifty adult people were studied. Nine various points on frontal bone, seven on parietal and six on occipital were located and their thickness were measured bilaterally with help of CT scan.

\section{Results}

The present study showed that Mean thickness ${ }_{+}$SD of frontal bone were $6.1+\ldots 1.8 \mathrm{~mm}$; parietal $4.6+2.2$ and occipital 9.5+ 3.4. The study also showed that frontal bone had $2 . \overline{4}+\ldots .8 \mathrm{~mm}$ thick outer table; $1.4+0.6 \mathrm{~mm}$ inner table and $3.5+\ldots 1.3 \mathrm{~mm}$ diploe. Similarly parietal bone had $1.9+[0.6$ $\mathrm{mm}$ thick outer table; $1.1+0.4 \mathrm{~mm}$ inner table and $0.8+0.5 \mathrm{~mm}$ diploe. The occipital bone had $3.5+1.5 \mathrm{~mm}$ thick outer table; $2.2+0.8 \mathrm{~mm}$ inner table and $4.3+\ldots 1.8 \mathrm{~mm}$ diploe. Similarly this present study also calculated the mean thickness+_SD of outer table in the calvarium as $2.7+1.3 \mathrm{~mm}$ and that of inner table $1.5+0.9 \mathrm{~mm}$. Thus it concluded that outer table was thicker than inner table.

Key words: skull, cranial vault, calvarium, diploe.

\section{Introduction}

Skull has cranial vault and base. The cranial vault is called as calvarium which roofs the cranial cavity (brain box).Cranial vault consists of frontal, parietal and occipital bones which develops from membranous ossification thus these are called membranous bones. Membranous bones are widely used in bone grafting because of greater acceptability in donor site. While evaluating the donor site, first surgeons should assess the thickness of bone in calvarium with help of Computerized tomography (CT) scan. Knowledge of calvarial thickness is also important for selection of screw length to be used in calvarial bones for fixation. Calvarial bone thickness can be measured with help of CT scan to determine 
Original Article

the length of screw that can be used without risk of penetrating the cranial cavity. Total thickness of calvarial bones includes outer table, diploe and inner table. Diploe is made up of spongy bone whereas outer and inner table made up of compact bone.

\section{Materials and methods}

A hospital based cross-sectional study was carried out with aim to measure the thickness of Nepalese calvarial bones i.e. Frontal, Parietal and Occipital. The CT records of One hundred and fifty adult people, over 20 years age were randomly selected for the study. However those who had history of trauma to skulls and bony pathology of skull bones were excluded in the study. Thicknesses of calvarial bones at various points were measured with the help of CT scan.

Thickness of various points on Frontal bone that were measured bilaterally:

$\mathrm{F} 1=$ near or on frontal tuberosity; $\mathrm{F} 2=$ near medial to tuberosities; F3=lateral to frontal tuberosity; F4=Thickness of frontal bone towards pterion; $\mathrm{F} 5=$ near to bregma; $\mathrm{F} 6=$ lateral to bregma; $\mathrm{F} 7=$ medial to frontal sinus; F8=lateral to frontal sinus; $F 9=$ cranial to frontal sinus.

Thickness of various points at Parietal bone that were measured bilaterally:

$\mathrm{P} 1=$ near or on Parietal eminence; $\mathrm{P} 2=$ Parietal bone near to Bregma; P3=Medial to parietal eminence; $\mathrm{P} 4=$ Lateral to parietal eminence; P5=Parietal bone near to Lamda; P6=Cranial to Pterion; $\mathrm{P} 7=$ Cranial to Asterion

Thickness of various points on Occipital bone that were measured bilaterally:

$\mathrm{O} 1=$ just posterior to Lamda; $\mathrm{O} 2=$ posterolateral to Lamda; O3=just posterior to asterion; $\mathrm{O} 4=$ medial to asterion towards midline;
Calvaria and Radiological Mapping

O5=near to External Occipital protuberance towards midline; O6=near to External Occipital protuberance laterally.

Statistical analysis was performed using the SPSS version 11.00. The arithmetic mean and standard deviation were calculated and one way ANOVA test was applied to test the significant difference among the mean thickness of Frontal, Parietal and Occipital bone as well as among the mean thickness of outer table, inner table and diploe of frontal, parietal and occipital bone. Student's unpaired ' $t$ 'test was applied to test the significant difference between the mean thickness of outer table and inner table.

\section{Result}

CT records of one hundred and fifty adult people were studied. Nine various points on frontal bone, seven on parietal and six on occipital were located and their thickness were measured bilaterally with help of CT scan.

Table 1: Comparison of mean thickness of Frontal, Parietal and Occipital bones $(n=150)$.

\begin{tabular}{|c|c|c|c|c|}
\hline Thickness & $\begin{array}{l}\text { Frontal } \\
\text { bone }\end{array}$ & $\begin{array}{l}\text { Parietal } \\
\text { bone }\end{array}$ & $\begin{array}{l}\text { Occipital } \\
\text { bone }\end{array}$ & $\begin{array}{l}P \\
\text { value }\end{array}$ \\
\hline $\begin{array}{l}\text { Mean } \\
\text { thickness } \\
(\mathbf{m m})+\text { SD }\end{array}$ & $\begin{array}{l}6.1+\_1.8 \\
\mathrm{~mm}\end{array}$ & $\begin{array}{l}4.6+2.2 \\
\mathrm{~mm}\end{array}$ & $\begin{array}{l}9.5+3.4 \\
\mathrm{~mm}\end{array}$ & 0.047 \\
\hline
\end{tabular}

There was significant difference among mean thickness of frontal, parietal and occipital bones $(p<0.05)$. 
Table 2: Comparison of mean thickness of outer table, inner table and diploe of Frontal, Parietal and Occipital bones $(\mathbf{n}=150)$.

\begin{tabular}{|c|c|c|c|c|}
\hline $\begin{array}{l}\text { Thickne } \\
\text { ss in } \\
\text { mm } \\
\text { Mean+- } \\
\text { SD) }\end{array}$ & $\begin{array}{c}\text { Frontal } \\
\text { bone }\end{array}$ & $\begin{array}{c}\text { Parietal } \\
\text { bone }\end{array}$ & $\begin{array}{l}\text { Occipital } \\
\text { bone }\end{array}$ & $P$ value \\
\hline $\begin{array}{l}\text { Outer } \\
\text { table }\end{array}$ & $\begin{array}{l}2.4+[0.8 \\
\mathrm{mm}\end{array}$ & $\begin{array}{l}1.9+\_0.6 \\
\mathrm{~mm}\end{array}$ & $\begin{array}{l}3.5+1.5 \\
\mathrm{~mm}\end{array}$ & 0.048 \\
\hline $\begin{array}{l}\text { Inner } \\
\text { table }\end{array}$ & $\begin{array}{l}1.4+[0.6 \\
\mathrm{mm}\end{array}$ & $\begin{array}{l}1.1+\ldots .4 \\
\mathrm{~mm}\end{array}$ & $\begin{array}{l}2.2+[0.8 \\
\mathrm{mm}\end{array}$ & 0.049 \\
\hline Diploe & $\begin{array}{l}3.5+1.3 \\
\mathrm{~mm}\end{array}$ & $\begin{array}{l}0.8+\ldots .5 \\
\mathrm{~mm}\end{array}$ & $\begin{array}{l}4.3+1.8 \\
\mathrm{~mm}\end{array}$ & 0.044 \\
\hline
\end{tabular}

There was significant difference among mean thickness of outer table, inner table and diploe of frontal, parietal and occipital bones $(p<0.05)$.

Table 3: Comparison of overall mean thickness of Outer and Inner tables of calvarium $(n=150)$.

\begin{tabular}{|l|l|l|l|}
\hline Thickness & $\begin{array}{c}\text { Outer } \\
\text { table }\end{array}$ & $\begin{array}{c}\text { Inner } \\
\text { table }\end{array}$ & P value \\
\hline $\begin{array}{l}\text { Mean } \\
\text { thickness } \\
(\mathrm{mm})+\text { SD }\end{array}$ & $\begin{array}{l}2.7+\_1.3 \\
\text { mm }\end{array}$ & $\begin{array}{l}1.5+\_0.9 \\
\text { mm }\end{array}$ & $\mathbf{0 . 0 4 1}$ \\
\hline
\end{tabular}

There was significant difference $(p<0.05)$ between mean thickness of outer and inner tables.

The present study calculated the mean thickness ${ }^{+}$SD of outer table in the calvarium as $2.7+\ldots 1.3 \mathrm{~mm}$ and that of inner table $1.5+\ldots .9$ $\mathrm{mm}$.

\section{Discussion}

CT records of one hundred and fifty adult people were studied. Nine various points on frontal bone, seven on parietal and six on occipital were located and their thickness were measured bilaterally with help of CT scan.

The present study showed that Mean thickness + SD of frontal bone was $6.1+\ldots 1.8 \mathrm{~mm} ;$ parietal $4.6+2.2 \mathrm{~mm}$ and occipital $9.5+3.4 \mathrm{~mm}$. There was significant difference among mean thickness of frontal, parietal and occipital bones $(p<0.05)$. The present study showed that frontal bone had $2.4+0.8 \mathrm{~mm}$ thick outer table; $1.4+0.6 \mathrm{~mm}$ inner table and 3.5+_1.3mm diploe. Similarly parietal bone had 1.9+_0.6 mm thick outer table; $1.1+0.4 \mathrm{~mm}$ inner table and $0.8+0.5 \mathrm{~mm}$ diploe. The occipital bone had $3.5+{ }_{-} 1.5 \mathrm{~mm}$ thick outer table; $2.2+0.8 \mathrm{~mm}$ inner table and $4.3+1.8 \mathrm{~mm}$ diploe. There was significant difference among mean thickness of outer table, inner table and diploe of frontal, parietal and occipital bones $(\mathrm{p}<0.05)$.

The present study calculated the mean thickness ${ }^{+}$SD of outer table in the calvarium as $2.7+1.3 \mathrm{~mm}$ and that of inner table $1.5+0.9$ $\mathrm{mm}$. There was significant difference $(\mathrm{p}<0.05)$ between mean thickness of outer and inner tables. It concluded that outer table was thicker than inner table.

Many investigators carried out computed tomographic study of calvarial bones in different perspectives.Gerhard W.Weber et.al carried out thickness mapping of the Occipital bone on CT-data and opined that information about the thickness of cranial bones are not only of great medical interest,particularly for pre-operative surgical planning, but can be useful for investigations of fossil hominid material. ${ }^{1}$ Kreiborg $\mathrm{S}$ et.al described and analyzed Apert and Crouzon skulls from threedimensional (3-D) reconstructions of CT-scans. 12 Apert patients and 19 with Crouzon syndrome were included in the study. A number of qualitative characteristics of the calvaria and cranial base were recorded and the cranial base angle was measured on the 3-D 
models. ${ }^{2}$ Hemmy DC and Tessier P studied CT of dry skulls with craniofacial deformities and assessed accuracy of three- dimensional reconstruction.In this study dry skulls from patients with Crouzon syndrome or orbital neurofibromatosis were studied using threedimensional reconstruction of computed tomography data. The images were compared with one another and with the actual skulls. It was concluded that the use of dry skulls is helpful in pointing out errors of inclusion or exclusion.

Thinner sections permit more accurate representation. Since reconstructed data do not appear to be significantly enhanced by using overlapping sections, radiation can be reduced by using abutting sections. ${ }^{3}$ Deborah R.Smith et,al Identified of human skeletal remains by comparision of bony details of the cranium using computerized tomographic(CT) scans. A case was described where a cranium from an unknown individual was identified by comparison of antemortem and postmortem computerized tomographic (CT) images of the bony structure of the skull.Bony details of the frontal and sphenoid sinuses, ethmoid and mastoid air cells, sagittal cranial suture, and the internal occipital protuberance were exactly the same on both CT scans, confirming them as the same person. ${ }^{4}$

Ross MD et.al investigated skull thickness of Black and White races and found that White women have the thickest and White men the thinnest skulls. The skulls of women were statistically significant thicker than those of men in both ethnic groups. ${ }^{5}$ Ross AH et.al had done research on cranial thickness in American females and males with an objective to examine sex and age variation in cranial thickness in a White sample.An increase in cranial thickness with age was observed and there was no statistical difference in calvarial thickness between male and female. ${ }^{6}$ Contrary to the Ross et.al finding,,Hatipoglu HG et.al found sexual dimorphism in all craniometric data observed positive correlation between body mass index and diploeic thickness. ${ }^{7}$ Hwang $\mathrm{K}$ et.al carried out thickness mapping of the parietal bone in Korean adults and concluded that the parietal bone tended to be thicker towards the Lamda point than at the coronal suture area. ${ }^{8}$ Daniel Novakovie et.al carried out computed tomographic analysis of outer calvarial thickness for osseointegrated bone-anchored hearing system insertion.A total of 195 temporal bones were examined in 100 patients;mean patient age was 60.9 years, of whom 54.4\% were males and $45.6 \%$ were females.Mean calvarial thickness was greatest at $+1 \mathrm{~cm}$ above external auditory canal level i.e. $6.3 \mathrm{~mm}^{9}$.

\section{Conclusion}

The present study studied CT records of one hundred and fifty adult people who had no history of trauma and bony pathology of calvarial bones. Nine various points on frontal bone, seven on parietal and six on occipital were located and their thickness were measured bilaterally with help of CT scan.

The present study showed that Mean thickness + SD of frontal bone was $6.1+1.8 \mathrm{~mm} ; \quad$ parietal $4.6+2.2 \mathrm{~mm}$ and occipital $9.5+3.4 \mathrm{~mm}$. The study also showed that frontal bone had $2.4+0.8 \mathrm{~mm}$ thick outer table; 1.4+ $0.6 \mathrm{~mm}$ inner table and $3.5+1.3 \mathrm{~mm}$ diploe.similarly parietal bone had $1.9+0.6 \mathrm{~mm}$ thick outer table; $1.1+0.4 \mathrm{~mm}$ inner table and $0.8+0.5 \mathrm{~mm}$ diploe. The occipital bone had $3.5^{-}+1.5 \mathrm{~mm}$ thick outer table; 2.2+ $0.8 \mathrm{~mm}$ inner table and $4.3++1.8 \mathrm{~mm}$ diploe.

The study calculated the mean thickness + SD of outer table in the calvarium as $2.7+1.3 \mathrm{~mm}$ and that of inner table 1.5+_0.9 mm. Thus it concluded that outer table was thicker than inner table. 


\section{References}

1. Weber GW, Johann K, Arnold N. Cassian C, Magori, Charles B, Saanane and Wolfagang. Thickness mapping of the occipital bone on CTdata.Acta Anthropologica Sinica Supplement 2000;19:37-46.

2. Kreiborg S, Marsh JL, Cohen MM ,Liversage M, Pedersen H, Skovby F, Borgesen SE, Vannier MW. Comparative three dimensional analysis of CT-scans of the calvaria and cranial base in Apert and Crouzon syndromes.Journal of cranio-maxillofacial surgery.1993;21(5):181-188.

3. Hemmy DC, Tessier PL. CT of dry skulls with craniofacial deformities: accuracy of threedimensionalreconstruction. Radiology. 1985; 157 : 113-116.

\section{Smith DR, Limbird KG, Hoffman JM.} Identification of human skeletal remains by Comparison of bony details of the cranium using computerized tomographic(CT) scans.J Forensic Sci.2002 Sept;47(5):937-9.
5. Ross MD ,Lee KA and Castle WM. Skull thickness of Black and White races.SAfr Med J 1976;50(16):635-8.

6. Ross AH, Jantz RL and Mc Cormick WF. Cranial thickness in American females and males. J Forensic Sci.1998;43(2):267-72.

7. Hatipoglu HG, Ozcan HN, Hatipoglu US, Yuksel E. Age,Sex and body mass index in relation to calvarial diploe thickness and craniometric data on MRI. Forensic Sci Int.2008Nov;182(13):46-51.

8. Hwang K, Kim JH, and Baik SH. Thickness mapping of the parietal bone in Korean adults.J.Craniofac.Surg.1997;8:208-12.

9. Novakovic D, Meller CJ, Makelam JM, Brazier D, Forer M, Patel NP. Computed Tomographic analysis of outer calvarial thickness for osseointegrated bone-anchored hearing system insertion.Otology and Neurology 2011;32(3):448-452.

Address of Correspondence: Manoj Bhattarai, Lecturer, Department of Radiodiagnosis and Imaging, Nobel Medical College Teaching Hospital and Research Center, Biratnagar. Email - drbhattaraimanoj@gmail.com 